\title{
Severe Hail Climatology of Turkey
}

A. Kahraman ${ }^{1,2, *}$, S. Tilev Tanriover ${ }^{1}$, M. Kadioglu ${ }^{1}$

(1) Istanbul Technical University, Dept. of Meteorological Eng., Istanbul, Turkey

(2) Turkish State Meteorological Service, ITU-TSMS Office, Istanbul, Turkey

$(*)$ e-mail: havadurumu@gmail.com

\section{ABSTRACT}

A climatology of severe hail for Turkey is being constructed using newspaper records, meteorological observations, government agencies and identical sources. Since hail is a small scale event in both spatial and temporal meanings, it is usually underreported especially over lesspopulated areas and during night time. Nonsevere hail which is not associated with important damage is also subject to underreporting. The preliminary results of the study includes over 600 records between 1950 and 2010, many of which does not have hail diameter, severity or time of the day information. Some of the records have photographs or videos enabling confirmation of the hail size, when some are depended upon eyewitnesses which are sometimes exaggerated (Fig 6, 7). The database is built up using the most reliable records. More than half of severe hail cases is expressed as walnut size. The largest reliably reported size of hail is $65 \mathrm{~mm}$ (90 grams) which is observed in Ankara in 06.05.1953, although 300-400 grams of hailstones have been observed in southeast according to some eyewitness records published at a major national newspaper. The collected data shows that hail in Turkey usually occurs in spring and summer months. Approximately 4/5 of the hailstorms are observed during afternoon and evening hours. However, morning hours also have significant number of records. The geographical distribution is more or less homogeneous, but the Mediterranean coast, Marmara region, northeast part of the country as well as central Anatolia have in particular higher records.

\section{Table 1: Classification of Hail

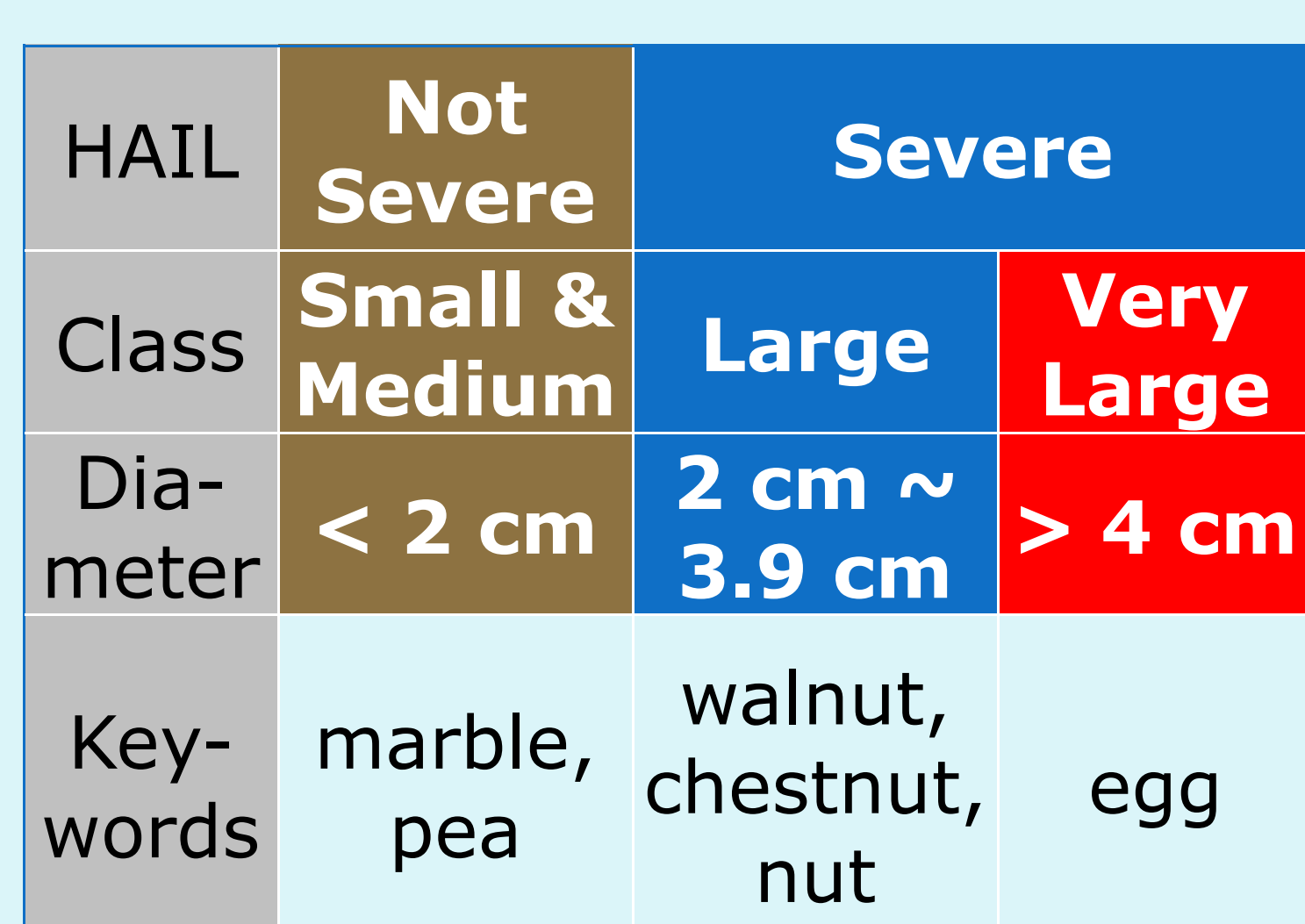

Severe Hail Days and Total Reliable Hail Cases

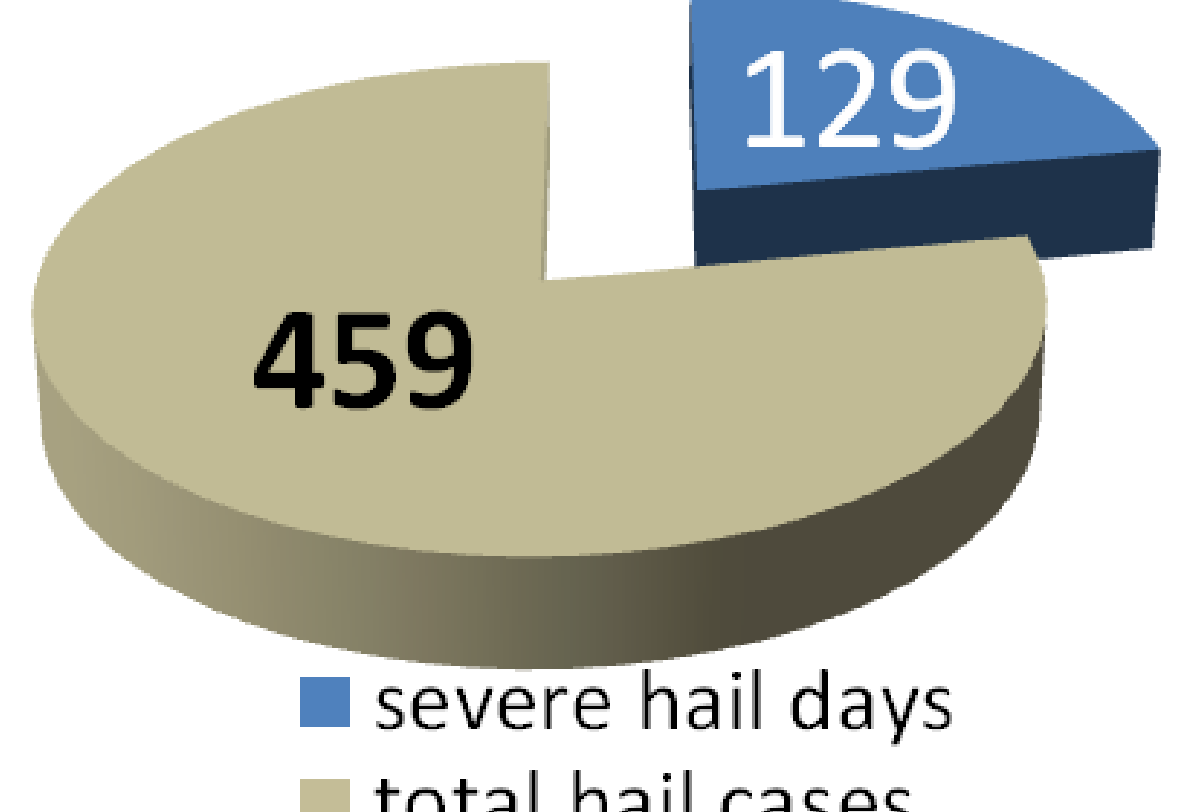

Figure 1: Severe Hail Days vs All Reliable Hail Cases

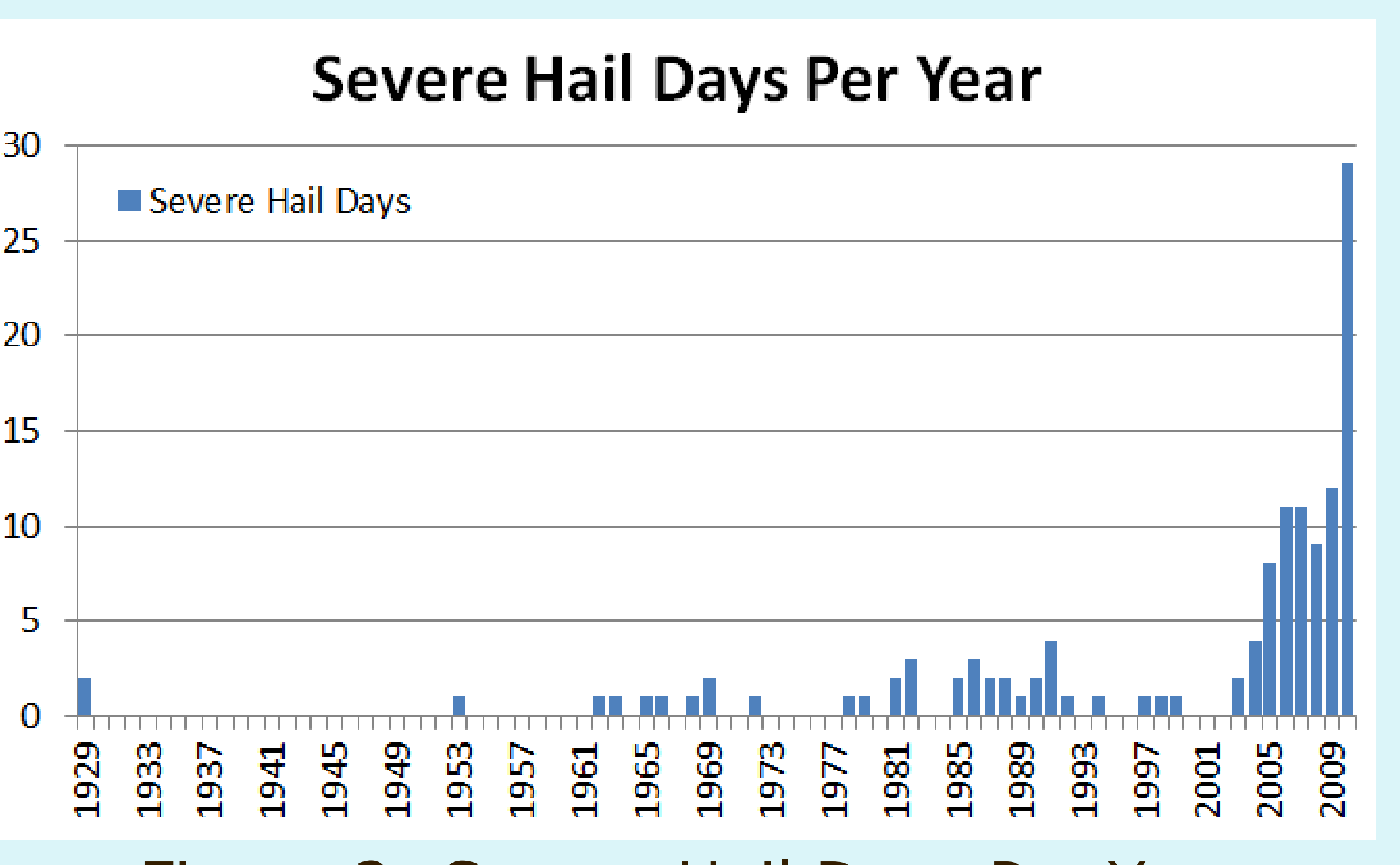

Figure 2: Severe Hail Days Per Year

Diurnal Distribution

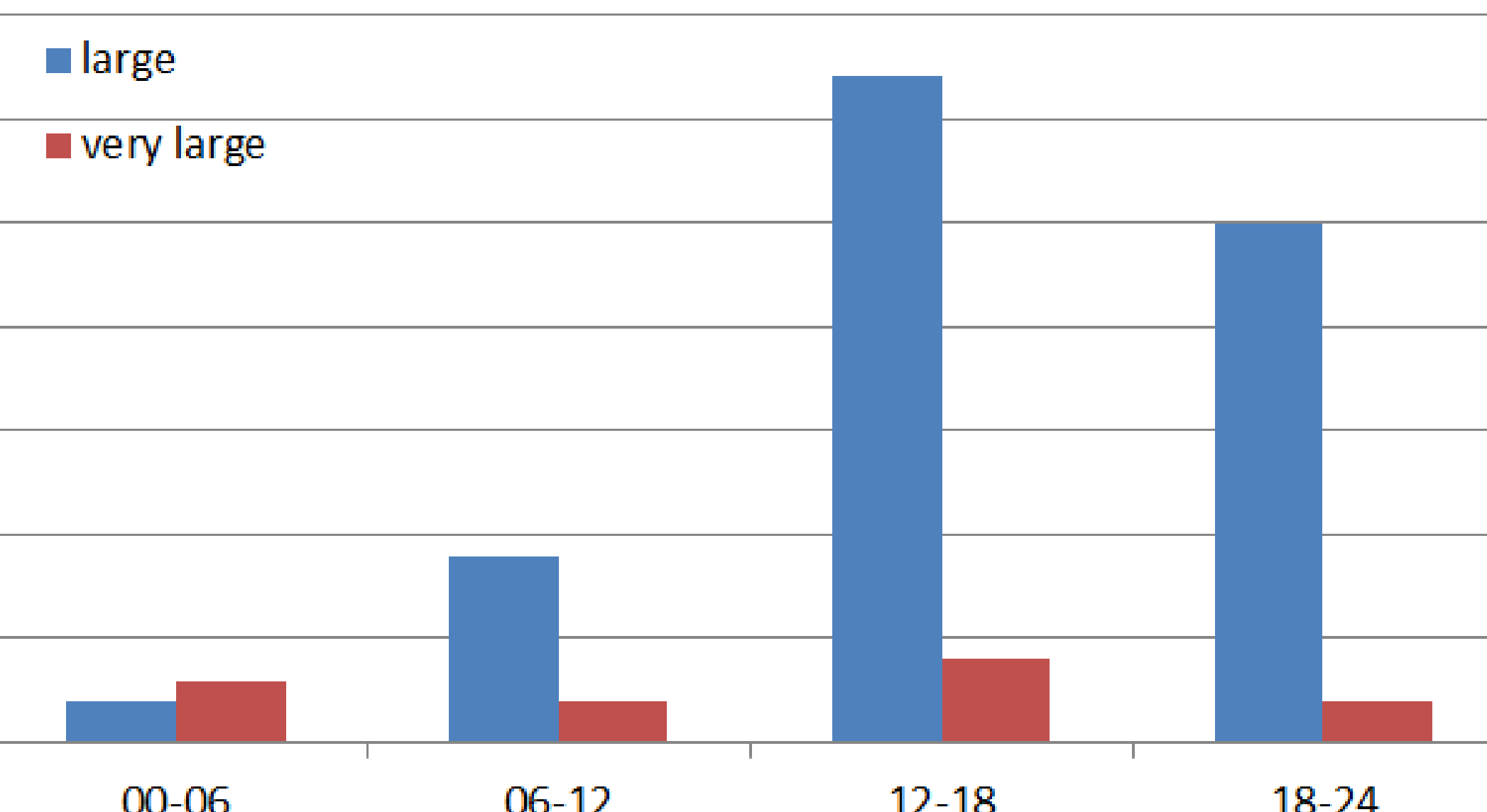

Severe Hail Days in Two-weekly Periods of The Year, 1929-2010

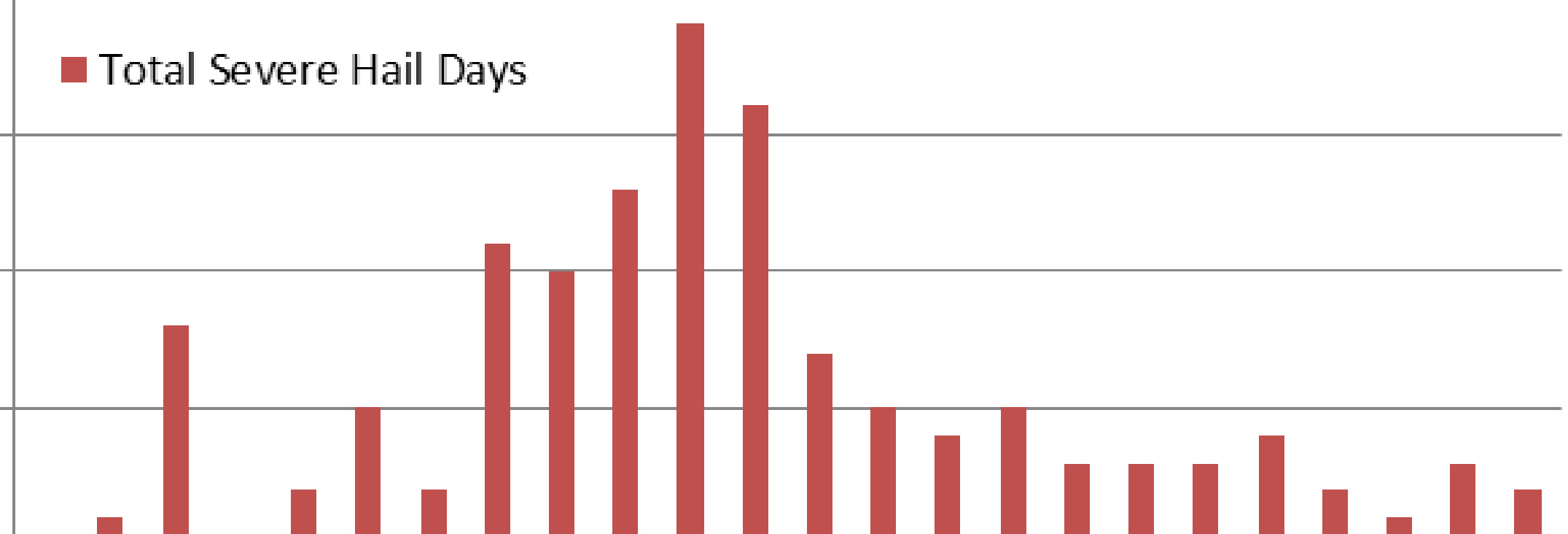

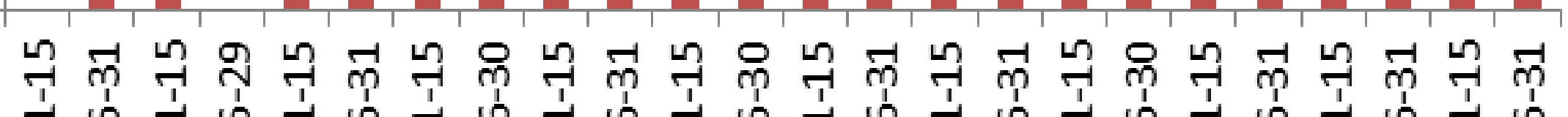

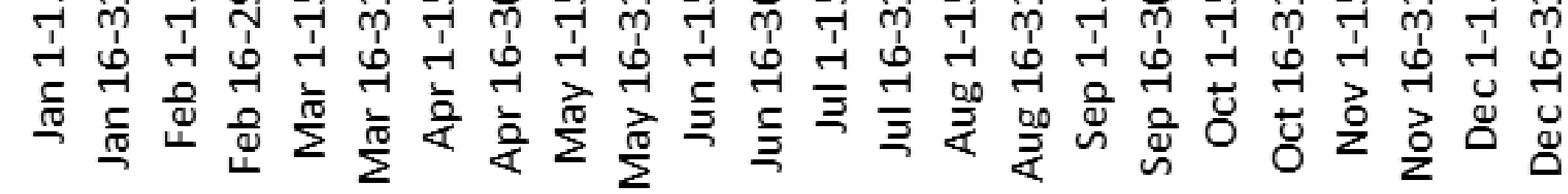

Figure 3: Severe Hail Days in Two-Week Periods of The Year between 1929-2010

Annual Distribution of Severe Hail

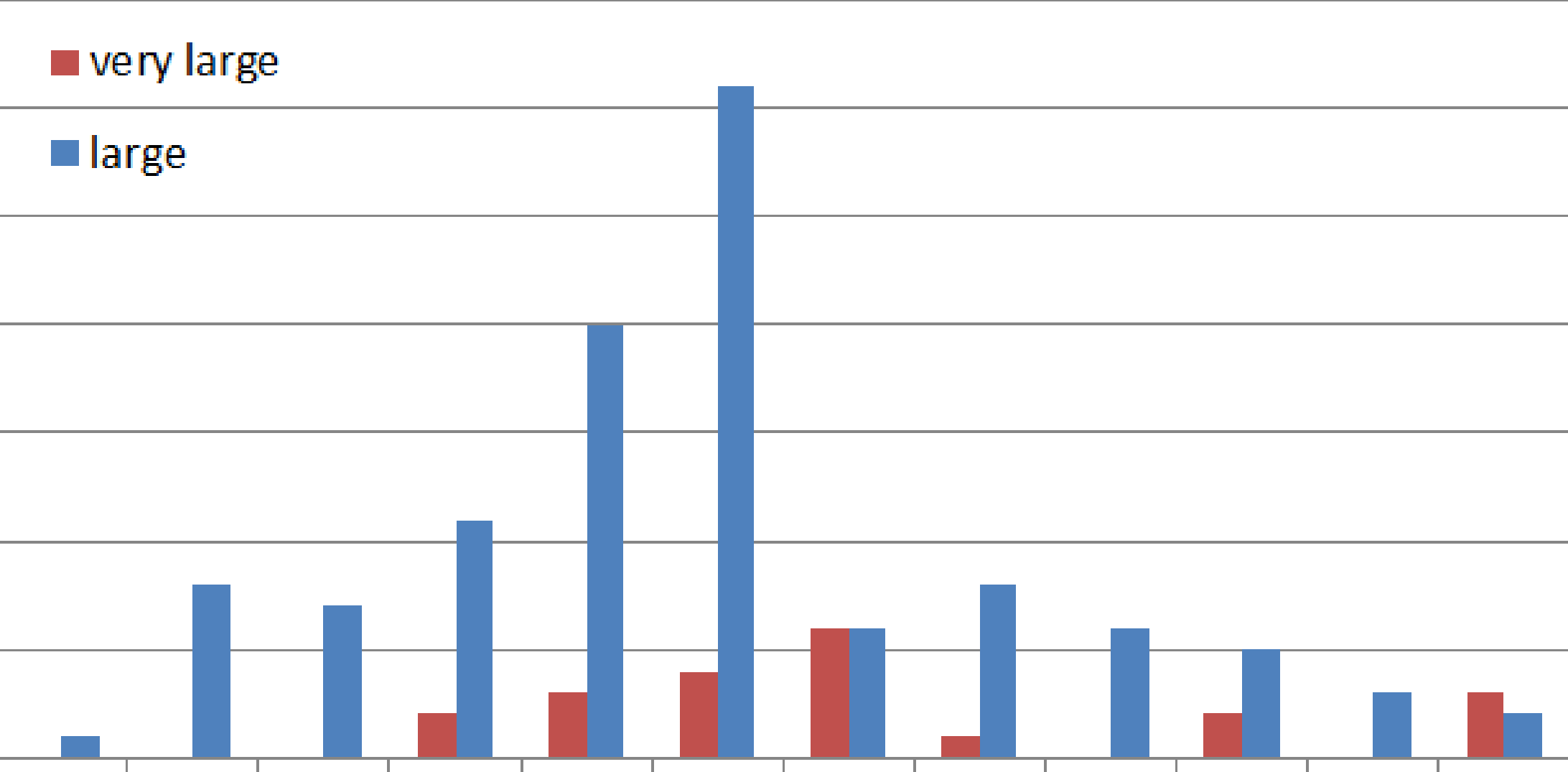

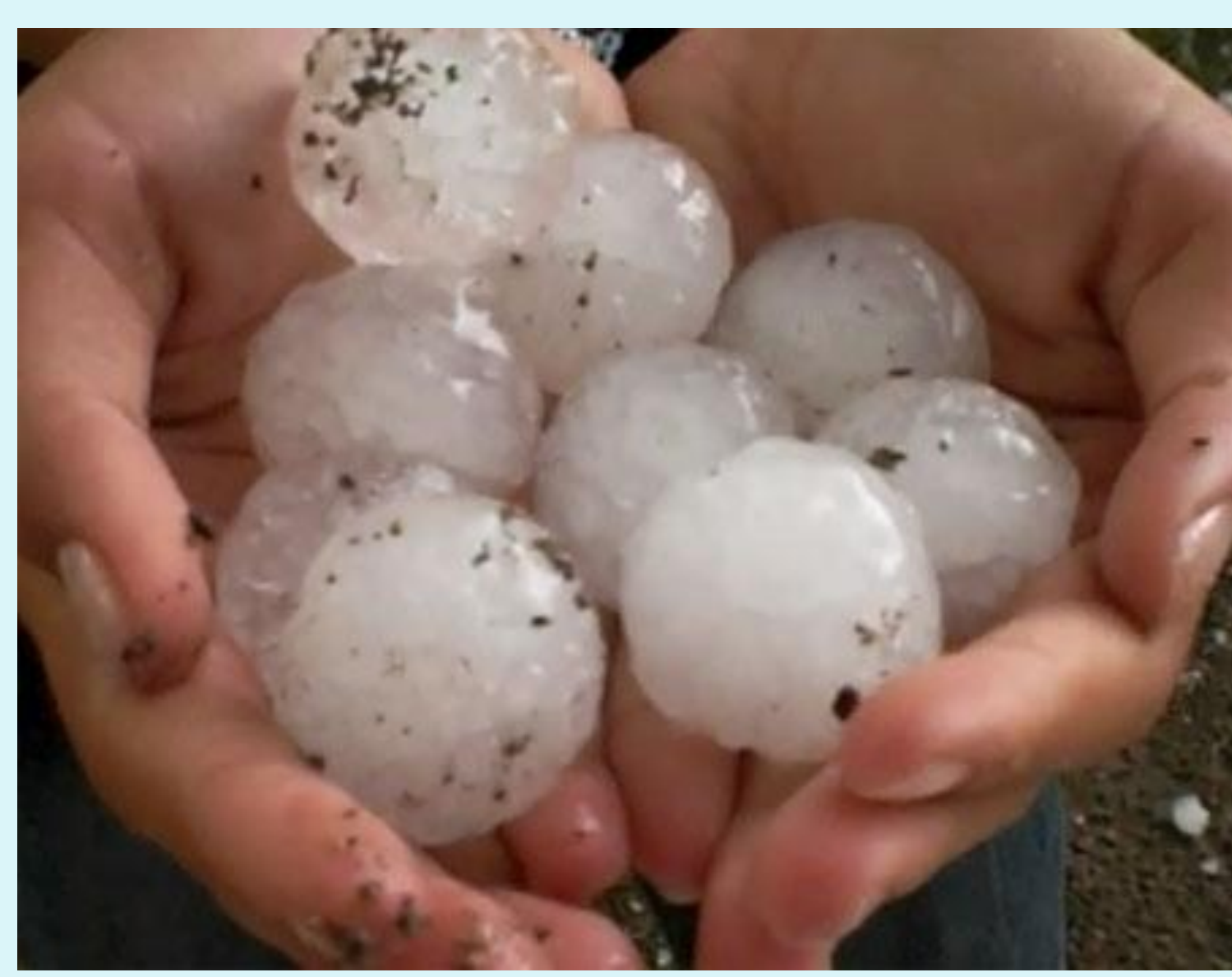

Figure 6: Hailstones in Ankara. Photo from CHA.

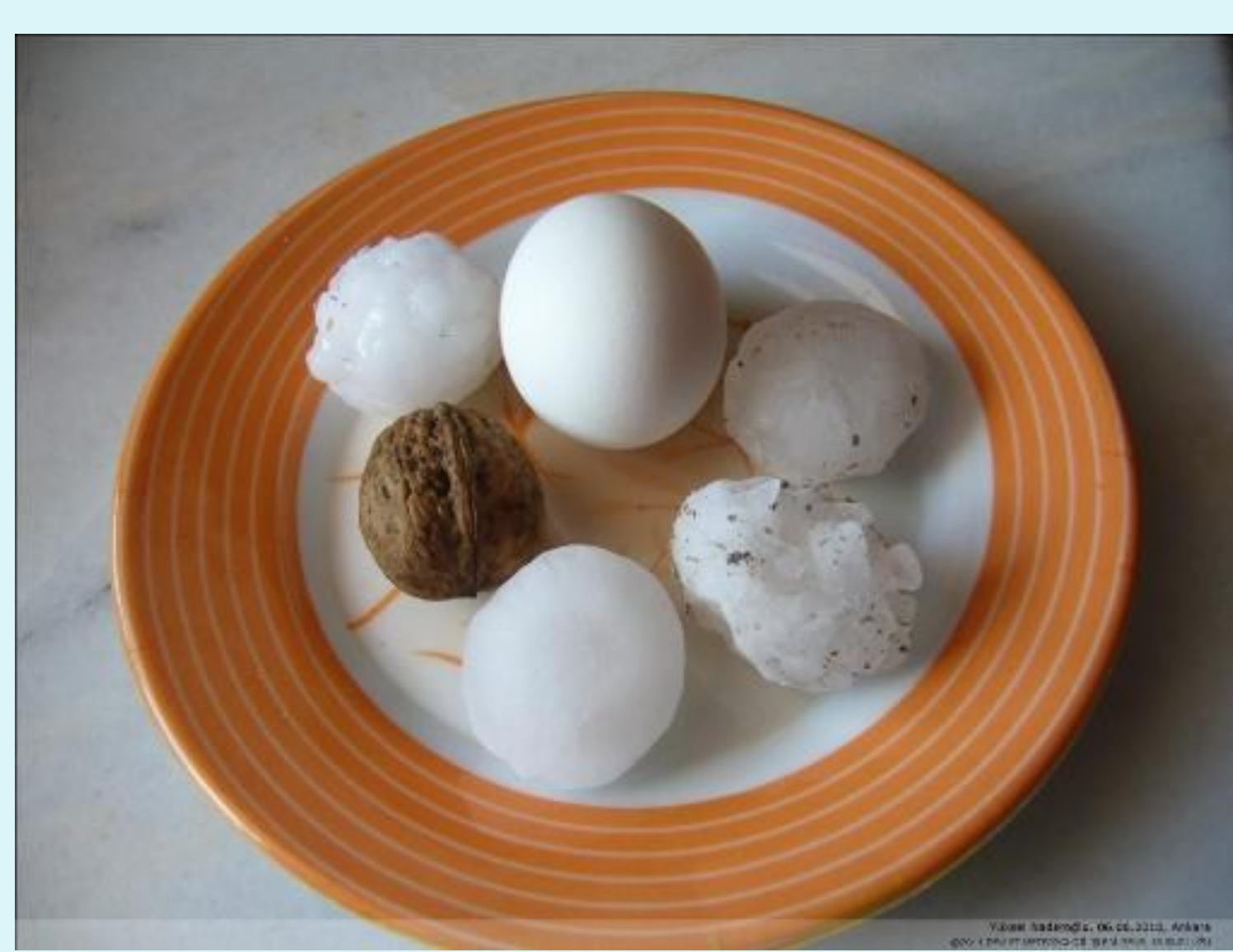

Figure 7: Hailstones in Ankara. Photo from TSMS website.

Figure 4: Diurnal Distribution of Severe Hail Figure 5: Annual Distribution of Severe Hail

\section{DATA \& CLASSIFICATION}

Severity of the hail is usually defined according to its diameter (Tuovinen et al (2009), Giaiotti et al (2003), Sioutas et al (2009), Webb et al (2009)).

In this study, hail with $2 \mathrm{~cm}$ diameter or larger is considered as severe (Table 1 ). More than $4 / 5$ of the records are from newspapers, which usually define the size with keywords like walnut, egg, etc. Major newspaper (Hurriyet, Cumhuriyet, etc.) and news agency (CHA, NTVMSNBC etc) archives are searched on internet and old copies are browsed in Beyazit State Library in Istanbul. Browsing process is still going on and different sources are being investigated. Number of severe hail days known so far is 129 (Fig 1 ).

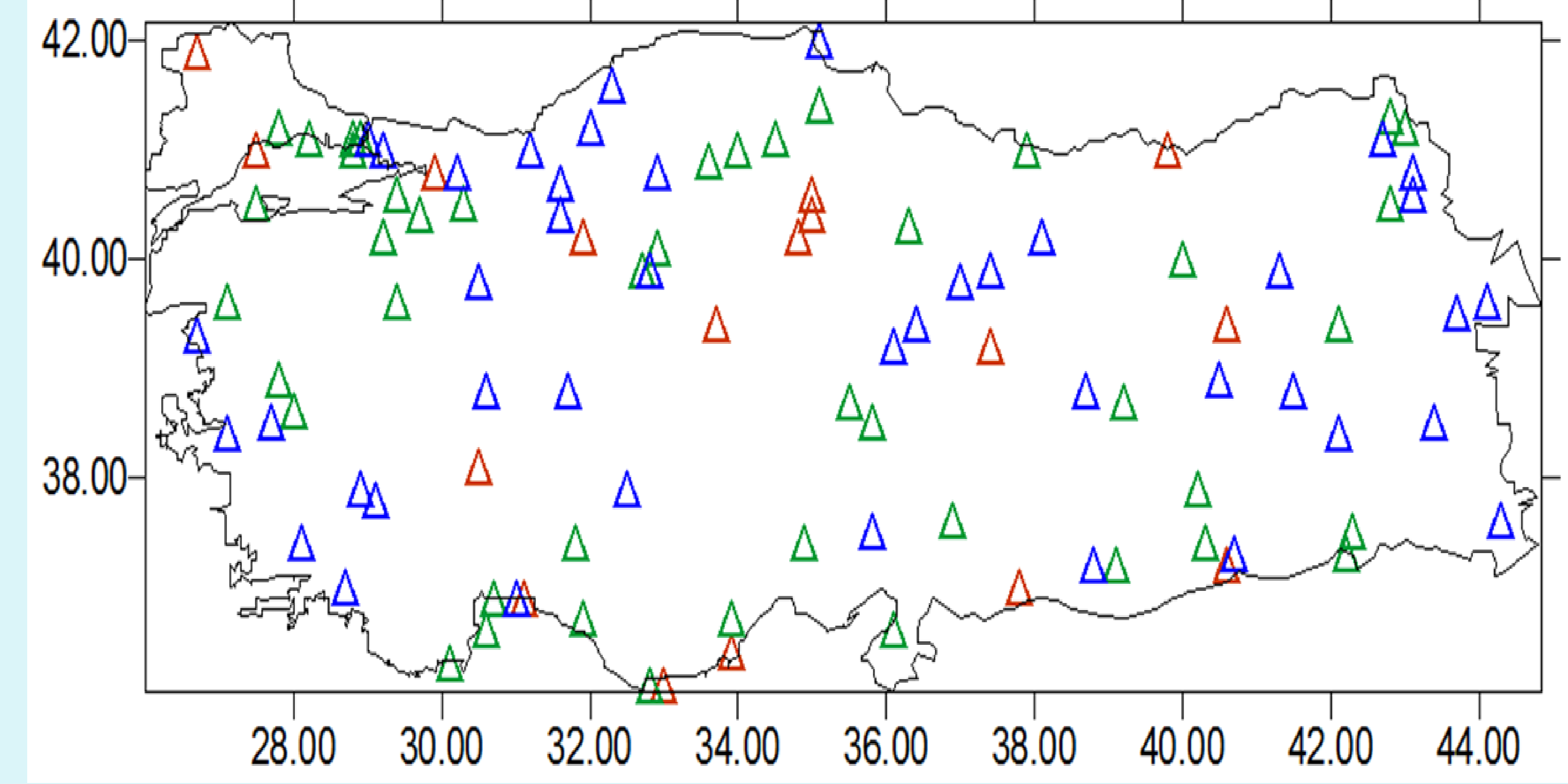

Figure 8: Geographical Distribution of Severe Hail. Blue triangles represent the large hail between 2 and $3 \mathrm{~cm}$ diameter size, where green represent hail with 3 to $4 \mathrm{~cm}$ diameter. Red triangles show very large hail occurences, namely diameter larger than $4 \mathrm{~cm}$.

\section{RESULTS}

It is obvious that most of the available records are from the last decade (Fig 2). According to the distribution of severe hail throughout the year (Fig 3), most of severe hail occurs between mid-April and mid-June in Turkey. Although large hail has a peak on June, very large hail has its peak on July, when large hail show an impressive decrease (Fig 5). Diurnal distribution of large hail shows a peak for afternoon and evening hours (Fig 4). During night time, very large hail is recorded more than large hail. Geographical distribution is more or less homogeneous (Fig 8).

\section{REFERENCES}

Giaiotti D., Nhe climatology of hail in the plain of Friuli Venezia Giulia, Atmospheric Research Vol 67-68, p 247-259. Sioutas M., Meaden T., Webb J.D.C. (2009), Hail frequency, distribution and intensity in Northern Greece, Atmospheric Research Vol 93, 526-533. Tuovinen J-P., Punkka A-J., Rauhala J., Hohti H., Schultz D.M. (2009), Climatology of Severe Hail in Finland, Monthly Weather Review Vol137, p 2238-2249. Webb J.D.C., Elsom D.M., Meaden G.T. (2009), Severe hailstorms in Britain and Ireland, a climatological survey and hazard assessment, Atmospheric Research Vol 93, p 587-606.

\section{SOME SIGNIFICANT HAILSTORMS}

06.05.1953, Ankara: 65 mm, 90 gr. No important damage is observed.

26.04.1963, Diyarbakır: Egg size. 35 injured and windows of about 1000 houses are broken in 9.5 minutes.

24.10.1969, Anamur: 70 gr. A few injured, flood due to hail resulted in damage in fields.

17.05.1982, Nizip: Egg size, some say 300 $-400 \mathrm{gr}$. Big damage in fields and towns. 06.07.1987, Kangal: 150 gr. 10 small cattle died, windows broken, huge damage. 23.10.1997, Serik. Egg size. Big damage in greenhouses and roofs.

29.06.2007, Alaca: Egg size. Some injured.

\section{ACKNOWLEDGEMENTS}

The authors thank to Dr. David M. Schultz for his suggestions, Dr. Abdullah Ceylan for his contribution to the data, Sedef Cakir for her help creating Figure 8, and European Meteorological Society for the Young Scientist Travel Award.

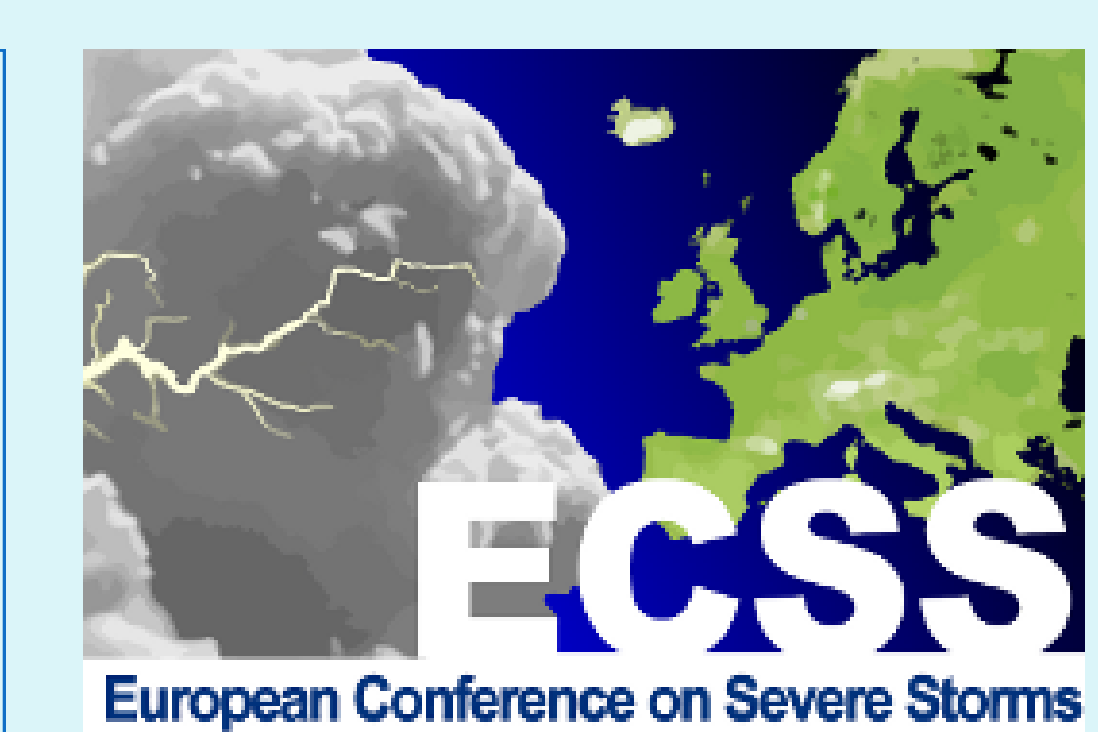

ECSS 2011

$6^{\text {th }}$ European Conference on Severe Storms 